Article

\title{
Finding Our Way to Food Democracy: Lessons from US Food Policy Council Governance
}

\author{
Karen Bassarab ${ }^{1, *}$, Jill K. Clark ${ }^{2}$, Raychel Santo ${ }^{1}$ and Anne Palmer ${ }^{1,3}$ \\ ${ }^{1}$ Center for a Livable Future, Department of Environmental Health and Engineering, The Johns Hopkins Bloomberg School \\ of Public Health, Baltimore, MD 21202, USA; E-Mails: kbanks10@jhu.edu (K.B.), rsanto1@jhu.edu (R.S.), \\ apalmer6@jhu.edu (A.P.) \\ 2 John Glenn College of Public Affairs, Ohio State University, Columbus, OH 43210, USA; E-Mail: clark.1099@osu.edu \\ 3 Department of Health, Behavior and Society, The Johns Hopkins Bloomberg School of Public Health, Baltimore, MD 21202 , \\ USA; E-Mail: apalmer6@jhu.edu \\ * Corresponding author
}

Submitted: 15 March 2019 | Accepted: 6 July 2019 | Published: 28 October 2019

\begin{abstract}
Food policy councils (FPCs) are an embodiment of food democracy, providing a space for community members, professionals, and government to learn together, deliberate, and collectively devise place-based strategies to address complex food systems issues. These collaborative governance networks can be considered a transitional stage in the democratic process, an intermediary institution that coordinates interests not typically present in food policymaking. In practice, FPCs are complex and varied. Due to this variety, it is not entirely clear how the structure, membership, and relationship to government of an FPC influence its policy priorities. This article will examine the relationship between an FPC's organizational structure, relationship to government, and membership and its policy priorities. Using data from a 2018 survey of FPCs in the United States by the Johns Hopkins Center for a Livable Future paired with illustrative cases, we find that an FPC's relationship to government and membership have more bearing on its policy priorities than the organizational structure. Further, the cases illustrate how membership is determined and deliberation occurs, highlighting the difficulty of including underrepresented voices in the process.
\end{abstract}

\section{Keywords}

collaborative governance; food democracy; food policy council; membership; participatory democracy

\section{Issue}

This article is part of the issue "New Perspectives on Food Democracy" edited by Basil Bornemann (University of Basel, Switzerland) and Sabine Weiland (Université Catholique de Lille, France).

(C) 2019 by the authors; licensee Cogitatio (Lisbon, Portugal). This article is licensed under a Creative Commons Attribution 4.0 International License (CC BY).

\section{Introduction}

Food policy councils (FPCs) are promoted as an expression of food democracy, creating a space for professionals, business, government, and community members to learn together and to galvanize collective action around policy strategies to address complex food systems issues. Food policy is a relatively new policy arena at the local level (Pothukuchi \& Kaufman, 2000); therefore, new forms of collaboration and governance, such as FPCs, emerge to serve as a voice for the community, in turn helping government to navigate its role in this arena (Mendes, 2008). FPCs work at scales not dominated by powerful global institutions (Sonnino, 2013) and challenge corporate hegemony in food and agriculture (Hassanein, 2003). They tend to tackle "wicked problems" that require boundary-spanning relationships among stakeholders across sectors based on trust, interdependence, and a need for new norms and approaches (Williams, 2002). FPCs provide a forum for a diversity of stakeholders to express their values and deliberate about how to change the food system. These fora reflect the 
unique history, political culture, and socioeconomic characteristics of a place, which is why no two FPCs are identical in form (Dahlberg, Clancy, Wilson, \& O'Donnell, 1997).

The scholarship on FPCs is inconsistent and incomplete in terms of understanding the influence of the form-hereafter considered to be organizational structure, relationship to government, and membership-of an FPC on its policy priorities and actions. The literature is mostly comprised of examination of FPCs of a particular organizational structure, such as those embedded in government versus those incorporated as a nonprofit organization, or case studies of individual FPCs.

This article seeks to understand how FPCs, as a vehicle for democratic participation, represent the values of a community. In particular, we analyze the relationship between structural factors and policy orientation, that is, how does an FPC's form influence the food systems issues (policy priorities) that an FPC decides to focus on? To answer this question, we first contextualize how FPCs and food democracy literature relate to concepts of participatory democracy and collaborative governance networks. Using data from a 2018 survey of FPCs by the Johns Hopkins Center for a Livable Future (CLF), we then explore the relationship between the form and policy priorities of FPCS across the United States (US). Following this analysis, we present three cases to illustrate how these relationships work in practice. Finally, we discuss the implications of key elements of our findings on FPCs' policy work and conclude with suggestions for further research on the processes of public participation in food democracy through FPCs.

\section{Food Democracy and Collaborative Governance}

The merits of representative versus direct democracy have been debated in the US since the late 18th century (Roberts, 2004). Key to the debate was, and continues to be, the extent to which government can accommodate citizen participation and whose values are represented in policymaking. The nature of problems facing the country have changed over the past two centuries (with greater complexity and globalized relationships), as have notions of representation by government officials. This debate and the changing nature of problems are not unique to the US. In the US, though, efforts by rights movements demanding greater participation of marginalized populations in political processes and by the federal government to urge citizen participation in government decisions have helped to codify expectations of participation (Roberts, 2004).

Food systems are one arena in which the legitimacy of representation by government is being challenged. Food democracy builds upon theories of direct citizen participation, whereby "members of society (those not holding office or administrative positions in government) share power with public officials in making substantive decisions and in taking actions related to the community" (Roberts, 2004, p. 320). Corporate consolidation of farm and food businesses, rising income inequality, and historic and systemic racial injustice all contribute to food system problems. Furthermore, citizens are skeptical about the federal government being representative of and accountable to all citizens. As growing corporate influence on federal food policy undermines citizens' desires for transparency in food production and distribution (Petetin, 2016), calls for consumers and producers to regain control of food systems through participation in local governance have emerged (Hassanein, 2003; Renting, Schermer, \& Rossi, 2012). Moreover, political gridlock has disrupted the federal food and agriculture policy regime, creating a space at the local level for collaboration and debate about whose values are being represented in public policy decisions about food (Hassanein, 2003; Renting et al., 2012; Sheingate, 2014).

FPCs provide a forum to practice food democracy by way of working with government rather than taking an adversarial approach (Andrée, Clark, Levkoe, \& Lowitt, 2019). They counter the problems of representational democracy serving mostly well-resourced interest groups by coordinating citizens, both lay stakeholders and paid professionals, from sectors and interests across the food supply chain and political institutions to address food system issues (Clancy, Hammer, \& Lippoldt, 2007). Lay stakeholders can be defined as "unpaid citizens who have a deep interest in some public concern and thus are willing to invest substantial time and energy to represent and serve those who have similar interests or perspectives but choose not to participate" (Fung, 2006, p. 68). Paid professionals include staff from nonprofit organizations that serve the interests of marginalized communities affected by food systems issues, small and mid-sized farm operators, farm workers, and local and regional farm and food businesses. Central to food democracy is participation by citizens or organizations representing citizens who have traditionally been excluded from political and economic processes.

FPCs are a participatory democratic undertaking that build on elements of both direct and representative democracy. While on the surface FPCs may appear to be in opposition to a representative democracy, in practice, they function as what public administration scholars call collaborative governance networks. FPCs embody a transitional stage in the democratic process by moving representative democracy away from the dominant neoliberal agenda toward greater citizen participation in response to the complexity of food systems problems (Klijn \& Skelcher, 2007). Food systems problems involve a multitude of ever-evolving, context-specific decisions about environmental resource allocation, economic viability, equity, and welfare across multiple levels of government. As public administration literature has expounded, policy solutions to complex problems, particularly at the local level, benefit from collaborative governance approaches (Emerson \& Nabatchi, 2015). Citizen participation in the policy process-from formation (input) to decisionmaking (throughput)-lends legitimacy to policies (out- 
put) as reflections of the values of citizens (Schmidt, 2013) and can lead to greater acceptance by the populace (Roberts, 2004). As collaborative governance networks, FPCs provide a space for citizens and government representatives to collectively navigate a policy problem and work towards shared goals. They engage citizens to build political capital and hold government accountable to the public interest (Schiff, 2008). In doing so, they add to the effectiveness of the policy process by making the process more transparent, inclusive and open (Bornemann \& Weiland, 2019; Harper, Shattuck, Holt-Giménez, Alkon, \& Lambrick, 2009; Schmidt, 2013; Sørensen \& Torfing, 2018).

Members of collaborative governance networks and their relationships can drive the networks' decisions and actions (Ansell \& Gash, 2008), and in the instance of FPCs, their eventual policy work (Koski, Siddiki, Sadiq, \& Carboni, 2018). Scholars have explored dynamics related to participation and representation on FPCs (Clancy et al., 2007; Dahlberg et al., 1997; Harper et al., 2009; Schiff, 2008), emphasizing that FPCs should take a systemsbased perspective on membership from across three axes: across domains (e.g., health, education, economic development), across the supply chain (e.g., production, retail, distribution), and across sectors (e.g., public, private, community; Irish, Clark, Banks, Palmer, \& Santo, 2017). Members become "boundary spanners" by crossing organizational and sector boundaries, creating a bridge that enables a systems-oriented approach (Williams, 2002). The specific permutation of members looks different for every FPC, as do the processes by which members engage in decisions and actions. The variations in FPC membership composition and processes reflect the dimensions of what Fung (2006) has termed the "democracy cube": who participates and how those participants are selected, the authority and power granted to participants, and how members derive decisions. The interaction of these dimensions influences the policy priorities and actions of FPCs.

Furthermore, membership alone does not necessarily translate directly to policy change. As Koski et al. (2018) point out, descriptive representation, or "representation on paper," is not substantive representation, or "representation in practice." In their study of one council, the authors found that who is at the table influences what is on the agenda, but it is not a clear oneto-one relationship (Koski et al., 2018). An overemphasis on process, open structure, unequal capacity and resources across members, and lack of a shared goal contributes to the discrepancy between descriptive and substantive representation (Koski et al., 2018). Findings from previous research on how other factors, such as organizational structure and relationship to government, influence the policy work of FPCs are mixed. For FPCs in California, structural autonomy alongside strong collaboration with government was key to creating more inclusive policies and building connections between community members and government (Gupta et al., 2018). Yet a study of FPCs across the US found that FPC structure may not be a significant factor in its policy strategies but may depend more on local influences and available resources (DiGiulio, 2017).

The forms and decision-making processes of FPCs are complex and varied. Due to this variety, it is unclear how the form-organizational structure, relationship to government, and membership-influences the policy priorities and subsequent actions of an FPC. This article only addresses part of this complex puzzle by examining if there is a relationship between an FPC's form and its policy priorities. This article focuses on the policy priorities of an FPC because the policy priorities drive where an FPC invests its resources. Policy priorities reflect the food systems issues that FPC members identify as critical to address collectively. Policy outputs (e.g., legislation) and policy outcomes (e.g., individual health changes) can take years to achieve (Sabatier \& Jenkins-Smith, 1999) and are difficult to track and measure for one FPC let alone across hundreds of FPCs. The outcomes of specific policy changes are especially hard to measure due to the complexity of interrelated elements across a system. These challenges with policy outputs and outcomes explain why the most comprehensive dataset available on FPCs, used for this article, only tracks FPC policy priorities. Using this dataset, we examine the patterns in the relationships between how an FPC is structured, how it works with government, and who participates in an FPC, and the FPC's policy priorities. In addition, we provide three cases to illustrate how these relationships play out in practice to create spaces for co-learning, deliberation, and decision-making.

\section{Methods}

We use a mixed methods approach to examine the relationship between an FPC's form-organizational structure, relationship to government, and membership-and its policy priorities. First, we provide descriptive statistics on characteristics of FPCS across the US. Next, we use quantitative analysis to examine broad patterns in the relationships between FPC form and policy priorities. Lastly, we provide three cases to illuminate how these relationships work in practice.

The data we use for the descriptive statistics and quantitative analysis come from an annual survey of FPCs conducted by CLF. The survey asks about an FPC's jurisdiction level, contact information, internet presence, year formed, governance structure, organizational and policy priorities, funding, influences on policy work, government levels and issue areas of policy work, and notable accomplishments. One member of the FPC completes the survey for the FPC. The survey was sent out to 380 FPCs. If no responses were received after two email reminders, council contacts were called up to two times before the survey was closed. Survey responses were received from $321 \mathrm{FPCs}$, but only responses from $222 \mathrm{FPCs}$ were analyzed for this article (our analysis excludes FPCs 
in Canada; those reporting to be inactive; ten duplicate survey responses; one response that did not qualify as an FPC; as well as FPCs that did not provide information on membership, reported an "other" organizational structure, or were developing policy priorities).

The survey tells us if and how an FPC is incorporated as an organization (referred to as organizational structure in the survey): 1) unincorporated or grassroots, 2) embedded-fiscally or administratively supported-in an institution or a nonprofit organization, and 3) standalone nonprofit organization. Additionally, the survey provides a crude assessment of membership; it only considers if a sector is represented among the membership of an FPC, not the total number of members nor number of members representing a sector. More importantly, the information collected through the survey does not tell us about the mechanisms of participation: how (if) members are selected and how decisions are made.

We employ the bivariate Chi-square $\left(\chi^{2}\right)$ test to examine patterns in relationships between an FPC's organizational structure, relationship to government or membership categories, and policy priorities (McCrumGardner, 2008). For example, this test allows us to compare FPCs that have and do not have a representative in a particular membership category (e.g., health care) and whether that FPC has a particular policy priority (e.g., healthy food access), creating a two-by-two matrix of possible results. Are differences in numbers in the cells of the matrix random chance, or is there a patterned difference between the two groups? A standard approach to determine significant relationships is a $p$-value of $<0.05$ (McCrum-Gardner, 2008); significant results mean that there is a correlation between the two nominal variables that we are testing (with a $95 \%$ certainty). However, $p$-values of up to 0.10 are common ( $90 \%$ certainty). Considering the literature recognizes that $p$-values are continuous and that any cut-off is arbitrary, we report any relationship up to a $p$-value of 0.10 . We did not test relationships with policy priorities when the food systems issue area had less than five observations because a sample size of fewer than five can be problematic. We therefore excluded the bivariate relationships with the policy priorities of food labor, natural resources and environment, transportation, and food processing. Further, while relying on $p$-values to determine significance is debated (Amrhein, Greenland, \& McShane, 2019), they can still be useful as one type of evidence when analyzing large datasets.

To illustrate some of the dynamics of the significant relationships we found in the statistical analysis, we provide three cases of FPCs in Baltimore (Maryland), Adams County (Pennsylvania), and Austin (Texas). The FPCs were purposely sampled to yield the most relevant data to illuminate gaps left by the survey data (Yin, 2015). They were selected based on the knowledge of the cases given established relationships between CLF staff and the FPC. This analysis uses a practitioner-action research framework which "is carried out by professionals who are en- gaged in researching...aspects of their own practice as they engage in that practice" (Edwards \& Talbot, 1994, p. 52, as cited in Denscombe, 2014, p. 127). Three of the authors are CLF staff who designed, conducted, and analyzed the survey used in this article. The other author serves as an adviser on the work of CLF with FPCs and is a member of a local FPC and a state FPC. Such positionalities provide us with rich experiences and context to inform this article, with the goal of creating findings that could be useful to FPCs (Denscombe, 2014). The content was gathered through personal knowledge of the FPCs and follow up with the FPCs for clarification. These cases offer a sampling of the breadth of mechanisms that FPCs use to engage participants.

\section{Findings}

In the following section, we present our findings from the quantitative analysis and illustrative cases. First, we detail the characteristics of FPCS across the US and then present our survey analysis examining broad patterns in the relationships between FPC form and policy priorities. Finally, we describe three cases to demonstrate how these relationships work in practice.

\subsection{FPCs in the United States}

FPCs have existed in the US since 1981, but have significantly increased in number over the last decade. Every year since 2009, 23 to 45 new FPCs were formed (Bassarab, Santo, \& Palmer, 2019). At the end of 2017, there were 284 active FPCs in the US, based on data collected from the annual survey of FPCs conducted by CLF, historical data about FPCs maintained by CLF, and data gathered from online searches to verify the active status of FPCs. FPCs or similar groups are emerging across the Global North, including in Canada, the United Kingdom, Germany, and several other countries (Santo \& Moragues-Faus, 2019).

FPCs in the US are heterogeneous. Each council weighs decisions about their geographic focus, organizational structure, structural autonomy from government, and membership against the political, social, economic, and demographic context of the area. Like a Rubik's cube, there are seemingly endless combinations but some characteristics are more common. Most FPCs (71\%) focus their work at the local level: city/municipality, county, or both city/municipality and county. Only $8 \%$ of FPCs work at the state level and $22 \%$ work at the regional level (multiple counties). Additionally, the majority of FPCs are embedded in an institution: $35 \%$ are sponsored by a nonprofit organization, $29 \%$ are embedded in government, and $6 \%$ are housed in a university. Another $18 \%$ are unincorporated (grassroots) groups and $12 \%$ are nonprofit organizations (Table 1).

Being embedded in government is only one way for FPCs to connect with government. An FPC may be created by legislation (17\% of FPCs); include government 
Table 1. FPC structure $(\mathrm{N}=222)$.

\begin{tabular}{lr}
\hline Structure & $\mathbf{N}$ \\
\hline Housed in a nonprofit & 78 \\
Embedded in government & 64 \\
Grassroots coalition & 39 \\
Nonprofit & 27 \\
Embedded in a university/college & 14 \\
\hline
\end{tabular}

employees or elected officials as members ${ }^{1}$ (86\%); have members appointed by government $(21 \%)$; receive inkind support-meeting space or administrative helpfrom government (40\%); or receive funding from government grants or appropriations (35\%)-Table 2. We also account for FPCs that have no relationship to government. A relationship with government can lend credibility and legitimacy to the work of an FPC and thus enable policy success, or it can hinder and even halt the efforts of an FPC (Clancy et al., 2007; Santo \& Moragues-Faus, 2019; Scherb, Palmer, Frattaroli, \& Pollack, 2012; Schiff, 2008).

Table 2. Relationship to government $(\mathrm{N}=222)$.

\begin{tabular}{lr}
\hline Relationship & $\mathbf{N}$ \\
\hline Government appointed members & 46 \\
Government staff and elected officials are & \\
$\quad$ members & 183 \\
In-kind support from government & 89 \\
Legislated by government & 37 \\
Financial support from government & 78 \\
No connection to government & 55 \\
\hline
\end{tabular}

FPCs' membership consists of professional stakeholders, public administrators, and elected officials from across the food supply chain and interrelated issue areas, e.g., environment, education, economic development, and health care. FPC membership also includes lay stakeholders, referred to as community members in the survey. FPCs could report their membership composition by selecting as many membership categories represented on their council as necessary (Table 3 ). On average, FPCs selected 10.84 (standard deviation 3.55) of the total 19 membership categories, with a range from 1 to 19 . The membership of the majority of FPCs (92\%) includes a community member. All but two FPCs have representation from professional sectors.

FPCs are woefully underfunded; $68 \%$ operate on an annual budget of $\$ 10,000$ or less (35\% have no funding). $12 \%$ have an annual budget over $\$ 100,000$. As FPCs mature, their funding increases slightly. Of the FPCs more than five years old, $29 \%$ have an annual budget over $\$ 25,000$, compared to $11 \%$ of FPCs that are five years or younger. The top three sources of financial support for FPCs are in-kind donations, non-federal government funding from grants or appropriations, and private foundations. A challenge consistently reported by FPCs on the annual survey is a lack of financial resources.

Table 3. Membership categories by FPC $(N=222)$.

\begin{tabular}{lr}
\hline Member Type & N \\
\hline Community & 204 \\
Public health & 194 \\
Anti-hunger/emergency food & 192 \\
College/university/community college & 186 \\
Food production & 185 \\
Government staff & 174 \\
Health care & 145 \\
Food retail & 123 \\
Economic development & 119 \\
Farm/food industry workers & 119 \\
Social justice & 112 \\
Elementary and secondary education & 111 \\
Faith-based organizations & 102 \\
Natural resources and environment & 100 \\
Food processing/distribution & 91 \\
Food waste/disposal & 76 \\
Elected official & 66 \\
Philanthropy & 59 \\
Youth & 49 \\
\hline
\end{tabular}

The charge of FPCs is to tackle issues facing their food system, but they do not work across the entire food supply chain simultaneously. To understand how an FPC approaches the food system at a given time, the survey asks FPCs to identify their top three policy priorities from a list of 11 food systems issue areas. For the past three years, healthy food access has been a priority for a majority of FPCs. In 2018, healthy food access, economic development, and anti-hunger were the most common policy priorities (Table 4). More recently, we have seen FPCs prioritizing food waste and food labor laws (Bassarab et al., 2019; Morrill, Santo, \& Bassarab, 2018).

Table 4. Policy priorities by FPC $(\mathrm{N}=222)$.

\begin{tabular}{lr}
\hline Policy Priority & $\mathbf{N}$ \\
\hline Healthy food access & 146 \\
Economic development & 96 \\
Anti-hunger & 81 \\
Food production & 69 \\
Food procurement & 63 \\
Land use planning & 58 \\
Food waste/recovery & 40 \\
Local food processing & 24 \\
Transportation & 18 \\
Natural resources and environment & 10 \\
Food labor & 4 \\
\hline
\end{tabular}

\footnotetext{
${ }^{1}$ Inclusion of government staff and elected officials in an FPC's membership was asked in the survey question about membership. We include the count of FPC membership with government staff and elected officials in both Tables 2 and 3 as this information is relevant to both an FPC's relationship to government and the composition of its membership. Table 2 shows the total number of FPCs with membership that includes a government employee, an elected official, or both. Table 3 shows the number of FPCs with membership that includes a government staff or an elected official. There were 57 FPCs with membership that included both a government employee and elected official.
} 
4.2. Patterns in Relationships between Form and Policy Priorities: Quantitative Results

Our findings on the relationships between an FPC's form and policy priorities from the bivariate analysis, shown in Table 5, demonstrate that membership composition and relationship to government have more bearing on the policy priorities of an FPC than the organizational structure. Organizational structure has one significant relationship to policy priorities, namely if an FPC is a grassroots coalition, embedded in a nonprofit, or a nonprofit itself, it is more likely to have policy priorities around production. In contrast, both membership and relationship to government have several significant relationships with policy priorities.
As Table 6 shows, most types of relationships that an FPC has with government have inverse relationships with some policy priorities. Seven out of the ten significant relationships suggest that FPCs put less priority on certain issues. In other words, having a relationship with government is related to what FPCs do not prioritize. For example, FPCs that are embedded in government, have government support (in-kind or financial), or have government-appointed members are less likely to prioritize food production policy issues. Conversely, FPCs with no connection to government are more likely to prioritize food production.

Overall, the relationships between a membership category and the corresponding policy priority are positively and significantly correlated (Table 7). Appendix A pro-

Table 5. Summary of bivariate relationships between form and policy priorities.

\begin{tabular}{ll}
\hline Form & Policy Priorities \\
\hline Organization type & One significant relationship to a policy priority with $p<0.10$ \\
\hline Relationship to government & $\begin{array}{l}\text { Ten significant relationships to policy priorities with } p<0.10 \text {; Five significant relationships } \\
\text { to policy priorities with } p<0.05\end{array}$ \\
\hline Membership & $\begin{array}{l}\text { Twenty-four significant relationships to policy priorities with } p<0.10 ; \text { Fifteen significant } \\
\text { relationship to policy with } p<0.05\end{array}$ \\
\hline
\end{tabular}

Table 6. Significant relationships between policy priorities and relationship to government.

\begin{tabular}{ll}
\hline Relationship to Government & Relationship to Policy Priority $(\boldsymbol{p}$-value) \\
\hline Embedded in government & Less prioritization of food production (0.077) \\
\hline Government appointed members & Less prioritization of food production (0.058) \\
\hline In-kind support from government & Less prioritization of food production (0.023) \\
\hline Financial support from government & Greater prioritization of food waste/recovery (0.034) \\
\hline Legislated by government & Less prioritization of food production (0.080) \\
& Greater prioritization of land use planning (0.076) \\
\hline No connection to government & Less prioritization of healthy food access (0.077) \\
& Greater prioritization of food waste/recovery (0.012) \\
\hline
\end{tabular}

Table 7. Membership significantly related to topically similar policy priorities.

\begin{tabular}{ll}
\hline Membership Category & Relationship to Policy Priority $(\boldsymbol{p}$-value) \\
\hline Anti-hunger/emergency food & Greater prioritization of anti-hunger $(0.001)$ \\
\hline Faith-based organizations & Greater prioritization of anti-hunger $(0.008)$ \\
\hline Food waste/recovery & Greater prioritization of food waste/recovery $(0.000)$ \\
\hline Food production & Greater prioritization of food production (0.080) \\
\hline Economic development & Greater prioritization of economic development (0.010) \\
\hline Elementary and secondary education & Greater prioritization of food procurement $(0.026)$ \\
\hline Food retail & Greater prioritization of food procurement (0.015) \\
\hline Youth & Greater prioritization of food procurement (0.067) \\
\hline
\end{tabular}


vides a full reporting of all relationships. The priorities of food waste/recovery, anti-hunger/emergency food, and land use planning have more significant relationships to membership categories than other priorities. One explanation is that some policy priorities are common across all FPCs (e.g., healthy food access) or prioritized overall by very few FPCs (e.g., land use planning). Additionally, some membership categories are related to more policy priorities than others. For example, having members representing faith-based organizations is significantly correlated to three of the seven policy priorities while members representing anti-hunger/emergency food are correlated with two policy priorities. Government staff, elected officials, and community members are not correlated with any policy priorities. Because nearly all FPCS have community members, we would not expect any significant differences in relationship to policy priorities across councils.

\subsection{Illustrations of Collaborative Governance and Food Democracy in Practice: Case Studies}

The three examples described below illustrate how members are engaged in the process of determining an FPC's policy priorities. In particular, these cases highlight the choices that FPCs make regarding who and how they recruit members, as well as the interplay between members, authority, and decision-making. The cases describe an open, self-selected membership process, an application process, and a process by which members are appointed. The FPCs featured work at different levels (city, city-county, county) and have different structures (initiative of city government, advisory board of city-county government, nonprofit in small town). These differences further contextualize the influence of an FPC's relationships to government and organizational structure on its policy priorities.

\subsubsection{Adams County, Pennsylvania}

Adams County, Pennsylvania, is a mostly rural county with an estimated population of just over 100,000 in 2017. The main town in the county, Gettysburg, had a population of around 7,600 in 2017. While the Adams County Food Policy Council (ACFPC) was established through a county proclamation in 2009, it is housed within Healthy Adams County, a nonprofit organization. The FPC's structure is non-hierarchical; there is no official leader, but logistics and meetings are coordinated by a facilitator. While membership is self-selecting and open to anyone who wants to participate, it mainly attracts professionals from government, academia, health care, and nonprofits working on related issues. Approximately 12 to 15 people regularly attend meetings in a volunteer capacity. Community input is sought periodically during a forum whereby anyone who wants to participate is invited to share their opinions and outreach to community members who receive services from organizations that participate in the ACFPC. This input informs the ACFPC's actions, although there is not a formal process for determining policy priorities.

At one forum, community members identified two issues affecting access to healthy food: the need for farmers and consumers to better understand each others' needs and constraints, and better advertisement and collaboration around existing healthy food initiatives. The ACFPC acted on this input by helping the Adams County Farmers Market Association (ACFMA) determine if closing a weekday market and only hosting a Saturday market would have a negative impact on low-income customers. To inform the ACFMA's decision, the ACFPC surveyed low-income participants of member organizations to see if dropping the weekday market day would severely hinder their ability to access healthy food. The conclusion was that while a small percentage of attendees could not attend a Saturday market, the majority could and would attend a market on Saturdays. The survey also provided the ACFPC an opportunity to increase understanding between farmers and consumers by talking about the implications for small farmers when business is much slower at the weekday market. The ACFPC keeps the discussions during the community fora in mind when making decisions about their priorities and actions.

\subsubsection{Baltimore, Maryland}

Baltimore is the largest city in the state of Maryland and has a majority African American population. Housed within the city government and funded by the city, the Baltimore Food Policy Initiative (BFPI) engages government staff, elected officials, and professional and lay stakeholders through three approaches: 1) intra-agency collaboration, 2) the Food Policy Action Coalition (FPAC), and 3) the Resident Food Equity Advisors (RFEA). The City's Food Policy Director and two staff housed in the Planning Department work with other government staff throughout the city on food systems issues.

FPAC is an open network of more than 60 selfselected people, mostly professionals from area nonprofit and community organizations, businesses, as well as university faculty and students whose work intersects with food systems. The network meets quarterly. This format allows for participation from a wider network of actors, but those who choose to participate in FPAC do not reflect the majority of Baltimore's population and are generally not people directly affected by food system problems (Swartz, Santo, \& Neff, 2018). Quarterly meetings consist of formal presentations and informal networking, whereby FPAC members learn from one another and share ideas with BFPI staff on current policy issues. FPAC members also approach BFPI staff as policy issues arise because of relationship building efforts by BFPI staff outside of the meetings. FPAC members' input, along with BFPI staff's own assessment of the feasibility of changing a policy, help BFPI select which policies to focus on. In this interaction, FPAC fulfills a comple- 
mentary role as described by Klijn and Skelcher (2007) to BFPI, allowing professional and lay stakeholders to listen and learn about policy issues in the city and to have their "say" in providing advice in the policy process.

Recognizing the need for a more deliberate means of eliciting residents' perspectives, BFPI formed the RFEA in 2017. Supported by a stipend, one resident from each council district in the city is selected through an application process to serve as an adviser to BFPI staff on food system issues facing the city. Over the course of six meetings, RFEA and BFPI staff convene to hear presentations from content experts, converse about their experiences related to the issue, deliberate about solutions, and craft appropriate policy recommendations. While BFPI staff make the final decision about recommendations, they are there to learn from residents about what they think will work. Advisers are invited to meet with their elected council member to share their experiences and to talk about the group's recommended food policy strategies. By recognizing and integrating the voices of those most affected by food policy decisions into their work, BFPI is facilitating a transition in democratic participation from representational to participatory democracy.

\subsubsection{Austin, Texas}

Austin, the state capital of Texas, is home to nearly a million people. Established in 2008 through local ordinances, the Austin Travis County Food Policy Board (ATCFPB) is a 13-member advisory board for the City of Austin and surrounding Travis County. Board members are appointed by the City Council and the County Commissioners. Members are encouraged to represent a diversity of sectors across the food supply chain but there are no required sector-specific positions. Appointed members decide which policies to recommend to local government staff and elected officials. The Board is supported by four working groups with open, self-selected membership and coordinated by City and County staff. Working groups serve as technical advisers to the Board around specific food systems issues. Citizens are invited to participate in a working group or to express their opinions during an allotted time at the beginning of the Board's monthly meetings.

As appointed representatives, Board members must navigate suggestions from self-selected members of working groups, the preferences of a broader network, as well as their own professional and personal interests. This balancing act led the Board to punt on a decision on a paid sick leave bill proposed by the Austin City Council. Faced with a recommendation from the Healthy Food Access Working Group to support the bill, as well as mixed recommendations to support and not support the bill from business and community organizations from the wider Austin community, the Board decided to neither support nor oppose the bill. The bill, however, was eventually passed by Austin City Council because of overwhelming support expressed by attendees at a commu- nity input meeting held by the Austin City Council (Morrill et al., 2018). At the center of the debate was a complex issue steeped in opposition from businesses that are better resourced and have more access to public officials than other stakeholders, such as workers and their representatives. Collaborative governance networks are prone to imbalance if there is not a way to equalize the capacity, resources, authority, and status of members (Ansell \& Gash, 2008). The ATCFPB tried to balance the views of proponents from the working group and community organizations with opposing views from Board members and businesses through a null vote. This vote held the ATCFPB accountable to both the Board and the working group but ultimately did not represent the desire of the community.

\section{Discussion}

The analysis above adds to the existing debate about how FPCs' forms relate to their policy work. Our findings demonstrate that membership and relationship to government have more bearing on the policy priorities of an FPC than the organizational structure (although the relationship to government is related to the lack of some priorities rather than their presence). Further, by illuminating the relationship between membership and policy priorities, and often policy development itself, the case studies underscore the role of FPCs as vehicles for food democracy. FPCs use a collaborative governance framework because it allows citizens with varying interests to grapple with the complexities of food systems issues, deliberate on appropriate and timely strategies, and collectively agree on directions to pursue for policy change.

This study shows that members matter; membership is related to a wide range of policy priorities. Some policy priorities have significant relationships with multiple membership categories. For example, the priority of food waste and recovery bears significant relationships with members representing anti-hunger organizations (recipients of excess food), food processing and distribution (involved in coordinating logistics for delivery of excess food), food waste, health care (for whom hunger and health are intricately linked), natural resources and environment (for whom wasted food represents wasted water and greenhouse gas emissions), and philanthropy. These relationships align with national campaigns to reduce food waste. This alignment raises questions about the degree to which national efforts influence the decisions of FPCs and whether FPCs can serve as a gateway to increase civic engagement at a national level.

Additionally, for some membership sectors, there is a relationship between the policy priority and the sector that the member represents. For instance, FPCs with members representing economic development are more likely to prioritize economic development policies while those with farmers, ranchers, or small producer advocacy groups are more likely to prioritize food production policies. The relationships between sector representation and policy priorities are of particular interest in con- 
sideration of whose values are being represented by the FPC. In an analysis of two local government planning processes, Baldy and Kruse (2019) point out that the values represented by members participating in the processes are complex and varied and based both on their personal experiences and professional role. Further research is needed to understand if members are representing the interests of their employer, an area of the food system for which they have a deep interest, or a particular demographic of the community.

FPCs struggle with community representation both in determining who counts as community members and how community members are included in FPC decisions. While most FPCs report to have members that represent the community, it is often unclear how FPCs define community members. Do they include lay stakeholders with a vested interest in an issue and willing to participate for free, people affected by problems with the food system, socially marginalized communities, lowincome communities, minority populations, or people traditionally excluded from economic and political processes? A few lay stakeholders amongst a dozen paid professionals could cause an imbalance in decision-making. Collaborative governance approaches can be designed to build the capacity of members at a disadvantage (Emerson \& Nabatchi, 2015).

Not all mechanisms for participation are equal, but the survey used for this article does not collect information about member selection (open, self-selecting, or targeted recruitment) or authority (voting members of a steering committee or non-voting expert advisers of a working group). These distinctions are important to understand the power dynamics among members in setting the policy agenda for an FPC. For instance, the ACFPC and the BFPI Resident Food Equity Advisors use an open, self-selecting process for member participation, yet mostly paid professionals participate. Such a format poses the risk that members are recruited through existing networks, which could inhibit inclusiveness and exacerbate inequity and underrepresentation of certain groups. Additionally, some members, such as professionals, may be perceived to have more expertise or authority because they have more resources and capacity. They may also represent the priorities of organizations outside of the community. Further, as Sieveking (2019) found with the Oldenburg FPC in Germany, openness of membership, and the resulting diversity, can bog down decision-making processes. Allowing elected officials to appoint members, such as the ATCFPB however, could also exclude stakeholders who traditionally lack economic capital, knowledge, or capacity to engage in the policy process. FPCs struggle to find a balance between harnessing the energy of those eager to transform food systems, learning from those with food systems and policy expertise, and empowering those impacted by food systems issues.

A membership process that deliberately places those who experience the effects of policy decisions in a po- sition to influence policy can add to the effectiveness and equity of policy decisions (Fung \& Wright, 2001). The BFPI Resident Food Equity Advisors program elevates the authority of residents in food policy decisions by specifically selecting residents to work directly with local government staff on policy recommendations. The ACFPC also tries to elevate the perspectives of residents who are affected by food systems issues in the FPC's decisions and actions through direct outreach to them. Our findings reinforce those of the Koski et al. (2018) case that the engagement process is important to ensure member representation on paper, in practice, and in the selection of policy priorities.

An FPC's relationship to government also bears a number of significant relationships to its policy priorities. Unlike membership, however, there is a significant inverse relationship between food production and an FPC's relationship to local government. One plausible explanation is that many regulatory issues (e.g., crop insurance, organic certification, food safety) facing farmers and ranchers are the result of federal policy decisions. While some FPCs do follow and advocate on federal policies, participation in the federal policy process requires different strategies and diminishes the effectiveness of policies to address place-based problems.

The aim of FPCs to create greater pathways for citizen participation in the policy process can only be achieved with government cooperation. Elected officials and public administrators must be willing to engage in colearning, deliberation, and power-sharing with members of society, as shown in the case of the BFPI RFEA program. The effectiveness and sustainability of an FPC as a collaborative governance network is questionable without this willingness. Other scholarship on FPCs has shown that an unwillingness by government staff to make the policy process accessible to citizens and attempts to impose the agenda of appointed or elected officials on an FPC can reduce the effectiveness or lead to the dissolution of FPCs (Coplen \& Cuneo, 2015; Gupta et al., 2018; van de Griend, Duncan, \& Wiskerke, 2019).

Organizational structure is not an irrelevant factor for FPCs, but our findings echo DiGiulio's (2017) findings that it does not drive policy decisions. An FPC's organizational structure can influence membership composition and the power dynamics amongst members, particularly for FPCs embedded in government or where members are appointed. In the case of the ATCFPB, the members appointed to the Board by local elected officials represented certain interests (e.g., businesses) that had opinions contrary to the desires of the community. For BFPI, an FPC embedded in government, determining its policy agenda and strategies often depends on political timing and agency collaboration and readiness.

\section{Conclusion}

Communities across the US are being confronted with food insecurity, unequal access to healthy food, family 
farm hardships, climate disruptions to food production, and other food systems related problems. Food democracy can be viewed as both a goal (output) to transform current food systems by addressing these problems that have arisen from imbalances in power, as well as a process of policymaking around food systems by (input) and with (throughput) citizens. We explore how collaborative governance networks in the form of FPCs are fora to engage citizens in the process of food democracy. The FPC framework is particularly useful for navigating the complexity of food systems and for negotiating policy strategies that address issues that members could not tackle alone. Our findings corroborate their collaborative nature, demonstrating that who sits on an FPC, and to a lesser extent, how they are connected to government, are key in shaping which issues FPCs address in their policy work. In this way, FPCs organize participation, and yet filter participation by determining rules for membership and decision-making.

These findings both reveal new insights and raise questions about FPCs' contributions to food democracy. On one hand, the importance of members' sectoral backgrounds in determining policy priorities underscores that their perspectives are informing which issues councils act on. On the other hand, there are dynamics of FPCs' decision-making process that we still do not fully understand. Issues of representation, power, and trust are not unique to FPCs. There may, however, be elements about the systems nature of food issues that make it uniquely challenging to focus the decisions and actions of an FPC, and to meaningfully incorporate perspectives from across the food system, especially of those who are traditionally excluded from the policy process. Additionally, while FPC membership fluctuates, policy change is a long game. Little is known about how transitions in membership affect the priorities and ultimate outcomes of FPCs. Future research could explore the power dynamics, policy deliberation, and conflict resolution processes involved in member participation on councils, particularly over time.

Since our analysis did not explore FPC policy outcomes, we are left with further questions around the goal of food democracy-that is, if and how FPC policy outcomes yield transformative food systems change. FPCs provide mechanisms for citizen participation in the policy process at local and state levels, but many of the challenges in the food system-especially those food democracy purports to address, such as corporate hegemony-stem from federal and global political decisions. Could FPCs build the capacity and interest of citizens to engage in higher levels of food policy advocacy? Does involvement with an FPC increase efficacy and encourage political participation beyond food systems? Amidst the current polarization and skepticism in US politics, the growing interest in FPCs may offer hope that people are recognizing the need to collaborate and (re)engage in democratic processes to ensure their values are reflected in policies at all levels of government.

\section{Acknowledgments}

We would like to thank all of the food policy council leaders who took the time to complete our survey and those who provided even more information to us by phone and email. We are also appreciative of Kate Clancy, Mark Winne, the thematic issue editors, and two anonymous reviewers for their valuable feedback that substantially improved our article.

\section{Conflict of Interests}

The authors declare no conflict of interests.

\section{References}

Amrhein, V., Greenland, S., \& McShane, B. (2019). Scientists rise up against statistical significance. Nature, 567, 305-307.

Andrée, P., Clark, J. K., Levkoe, C. Z., \& Lowitt, K. (2019). Civil society and social movements in food system governance. New York, NY: Routledge.

Ansell, C., \& Gash, A. (2008). Collaborative governance in theory and practice. Journal of Public Administration Research and Theory, 18(4), 543-571.

Baldy, J., \& Kruse, S. (2019). Food democracy from the top down? State-driven participation processes for local food system transformations towards sustainability. Politics and Governance, 7(4), 68-80.

Bassarab, K., Santo, R., \& Palmer, A. (2019). Food policy council report 2018. Baltimore, MD: Johns Hopkins Center for a Livable Future.

Bornemann, B., \& Weiland, S. (2019). Empowering people: Democratising the food system? Exploring the democratic potential of food-related empowerment forms. Politics and Governance, 7(4), 105-118.

Clancy, K., Hammer, J., \& Lippoldt, D. (2007). Food policy councils: Past, present, and future. In C. C. Hinrichs \& T. A. Lyson (Eds.), Remaking the North American food system: Strategies for sustainability (pp. 121-143). Lincoln, NE: University of Nebraska.

Coplen, A. K., \& Cuneo, M. (2015). Dissolved: Lessons learned from the Portland Multnomah food policy council. Journal of Agriculture, Food Systems, and Community Development, 5(2), 91-107.

Dahlberg, K. A., Clancy, K., Wilson, R. L., \& O'Donnell, J. (1997). Strategies, policy approaches, and resources for local food system planning and organizing: $A$ resource guide prepared by the local food system project team. Kalamazoo, MI: Western Michigan University.

Denscombe, M. (2014). The good research guide for small scale social research projects (5th ed.). Maidenhead: Open University Press.

DiGiulio, L. (2017). Food policy councils: Does organization type matter? (Unpublished Masters dissertation). The Ohio State University, Columbus, USA.

Emerson, K., \& Nabatchi, T. (2015). Collaborative gover- 
nance regimes. Washington, DC: Georgetown University Press.

Fung, A. (2006). Varieties of participation in complex governance. Public Administration Review, 66(Suppl. 1), 66-75.

Fung, A., \& Wright, E. O. (2001). Deepening democracy: Innovations in empowered participatory governance. Politics \& Society, 29(1), 5-41.

Gupta, C., Campbell, D., Munden-Dixon, K., Sowerwine, J., Capps, S., Feenstra, G., \& Kim, J. V. S. (2018). Food policy councils and local governments: Creating effective collaboration for food systems change. Journal of Agriculture, Food Systems, and Community Development, 8(Suppl. 2), 11-28.

Harper, A., Shattuck, A., Holt-Giménez, E., Alkon, A., \& Lambrick, F. (2009). Food policy councils: Lessons learned. Oakland, CA: Food First.

Hassanein, N. (2003). Practicing food democracy: A pragmatic politics of transformation. Journal of Rural Studies, 19(1), 77-86.

Irish, A., Clark, J., Banks, K., Palmer, A., \& Santo, R. (2017). Food policy growth and evolution: Evaluating development of roles and objectives of U.S. food councils over time. Paper presented at 78th Annual American Society for Public Administration Conference, Atlanta, GA, USA.

Klijn, E. H., \& Skelcher, C. (2007). Democracy and governance networks: Compatible or not? Public Administration, 85(3), 587-608.

Koski, C., Siddiki, S., Sadiq, A.-A., \& Carboni, J. (2018). Representation in collaborative governance: A case study of a food policy council. American Review of Public Administration, 48(4), 359-373.

McCrum-Gardner, E. (2008). Which is the correct statistical test to use? British Journal of Oral and Maxillofacial Surgery, 46(1), 38-41.

Mendes, W. (2008). Implementing social and environmental policies in cities: The case of food policy in Vancouver, Canada. International Journal of Urban and Regional Research, 32(4), 942-967.

Morrill, V., Santo, R., \& Bassarab, K. (2018). Shining a light on labor: How food policy councils can support food chain workers. Baltimore, MD: Johns Hopkins Center for a Livable Future.

Petetin, L. (2016). Food democracy in food systems. In P. B. Thompson \& D. M. Kaplan (Eds.), Encyclopedia of food and agricultural ethics. Dordrecht: Springer Netherlands.

Pothukuchi, K., \& Kaufman, J. L. (2000). The food system: A stranger to the planning field. Journal of the American Planning Association, 66(2), 113-124.

Renting, H., Schermer, M., \& Rossi, A. (2012). Building food democracy: Exploring civic food networks and newly emerging forms of food Citizenship. International Journal of Sociology of Agriculture \& Food, 19(3), 289-307.

Roberts, N. (2004). Public deliberation in an age of direct citizen participation. American Review of Public Administration, 34(4), 315-353.

Sabatier, P. A., \& Jenkins-Smith, H. C. (1999). The advocacy coalition framework: An assessment. In P. A. Sabatier (Ed.), Theories of the policy process (pp. 117-166). Boulder, CO: Westview Press.

Santo, R., \& Moragues-Faus, A. (2019). Towards a translocal food governance: Exploring the transformative capacity of food policy assemblages in the US and UK. Geoforum, 98, 75-87.

Scherb, A., Palmer, A., Frattaroli, S., \& Pollack, K. (2012). Exploring food system policy: A survey of food policy councils in the United States. Journal of Agriculture, Food Systems, and Community Development, 2(4), 3-14.

Schiff, R. (2008). The role of food policy councils in developing sustainable food systems. Journal of Hunger \& Environmental Nutrition, 3(2/3), 206-228.

Schmidt, V. A. (2013). Democracy and legitimacy in the European Union revisited: Input, output and 'throughput'. Political Studies, 61, 2-22.

Sheingate, A. (2014). The new politics of food in the United States. Paper presented at ECPR General Conference, Glasgow, Scotland.

Sieveking, A. (2019). Food policy councils as loci for practising food democracy? Insights from the case of Oldenburg, Germany. Politics and Governance, 7(4), 48-58.

Sonnino, R. (2013). Local foodscapes: Place and power in the agri-food system. Acta Agriculturae Scandinavica, Section B-Soil \& Plant Science, 63(Suppl. 1), 2-7.

Sørensen, E., \& Torfing, J. (2018). The democratizing impact of governance networks: From pluralization, via democratic anchorage, to interactive political leadership. Public Administration, 96(2), 302-317.

Swartz, H., Santo, R., \& Neff, R. A. (2018). Promoting sustainable food system change amidst inequity: A case study of Baltimore, Maryland. In D. Barling \& J. Fanzo (Eds.), Advances in food security and sustainability (Vol. 3, pp. 135-176). Cambridge, MA: Elsevier.

van de Griend, J., Duncan, J., \& Wiskerke, J. S. C. (2019). How civil servants frame participation: Balancing municipal responsibility with citizen initiative in Ede's food policy. Politics and Governance, 7(4), 59-67.

Williams, P. (2002). The competent boundary spanner. Public Administration, 80(1), 103-124.

Yin, R. K. (2015). Qualitative research from start to finish (2nd ed.). New York, NY: Guilford Publications. 


\section{About the Authors}

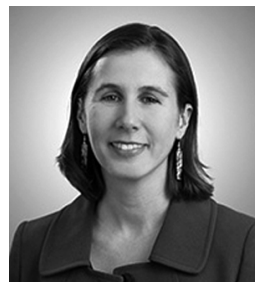

Karen Bassarab is a Senior Research Program Manager at the Johns Hopkins Center for a Livable Future, where she manages the Food Policy Networks project. Karen's research interests include local and regional food systems policy, community engagement, and food access and the built environment. Karen earned a Master's degree in Community and Regional Planning and Public Policy at the University of Texas at Austin.

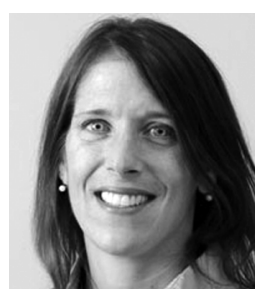

Jill K. Clark is Associate Professor in the John Glenn College of Public Affairs at Ohio State University. Her research interests include food policy and practice, centering on community and state governance of food systems, the policy process, and public participation. Current research topics include food policy coalitions, food system planning, value(s)-added food and agricultural development.

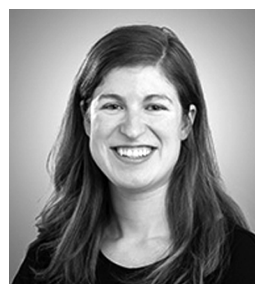

Raychel Santo is a Senior Research Program Coordinator at the Johns Hopkins Center for a Livable Future, where she works on research projects related to local and regional food governance, urban agriculture, institutional food procurement, and the relationship between diet and climate change. Raychel earned her Master's degree in Food, Space \& Society from Cardiff University School of Geography \& Planning and her BA in Public Health and Environmental Change \& Sustainability from Johns Hopkins University.

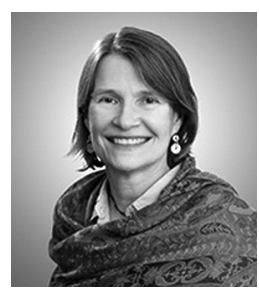

Anne Palmer is a Program Director at the Johns Hopkins Center for a Livable Future and a senior research associate at the Bloomberg School of Public Health in the Department of Health, Behavior and Society. She directs the Food Policy Networks project, which seeks to improve the capacity of food policy councils to advance food system policies. Anne's research interests include food retail, food policy, food environments, obesity, urban agriculture, local and regional food systems, and community food security. 
Appendix. Membership categories by policy priorities $(N=222)$. Note: Only two of the four cells are shown from each chi-square test. The two cells shown are those FPCs with members in the category and the two cells not shown are the cells for FPCs without that membership category.

Table A1. Food procurement.

\begin{tabular}{lrrr}
\hline Member Category & No & Yes & $p$-value \\
\hline Government staff & 125 & 49 & 0.891 \\
Elected officials & 48 & 18 & 0.812 \\
Anti-hunger/emergency food & 141 & 51 & 0.129 \\
College/university/community college & 132 & 54 & 0.623 \\
Community & 147 & 57 & 0.627 \\
Economic development & 80 & 39 & 0.118 \\
Elementary and secondary education & 72 & 39 & 0.026 \\
Faith-based organizations & 69 & 31 & 0.433 \\
Farm/food industry workers & 84 & 35 & 0.714 \\
Processing and distribution & 65 & 26 & 0.985 \\
Food production & 133 & 52 & 0.842 \\
Food retail & 80 & 43 & 0.015 \\
Food waste/recovery & 53 & 23 & 0.653 \\
Health care & 105 & 40 & 0.719 \\
Natural resources and environment & 74 & 28 & 0.778 \\
Philanthropy & 40 & 19 & 0.447 \\
Public health & 136 & 58 & 0.186 \\
Social justice & 82 & 30 & 0.595 \\
Youth & 30 & 19 & 0.067 \\
\hline
\end{tabular}

Table A2. Healthy food access.

\begin{tabular}{llrr}
\hline Member Category & No & Yes & $\boldsymbol{p}$-value \\
\hline Government staff & 55 & 119 & 0.117 \\
Elected officials & 23 & 43 & 0.900 \\
Anti-hunger/emergency food & 64 & 128 & 0.474 \\
College/university/community college & 68 & 118 & 0.097 \\
Community & 70 & 134 & 0.933 \\
Economic development & 43 & 76 & 0.521 \\
Elementary and secondary education & 34 & 77 & 0.258 \\
Faith-based organizations & 32 & 68 & 0.525 \\
Farm/food industry workers & 42 & 77 & 0.721 \\
Processing and distribution & 31 & 60 & 0.965 \\
Food production & 66 & 119 & 0.311 \\
Food retail & 44 & 79 & 0.590 \\
Food waste/recovery & 29 & 47 & 0.374 \\
Health care & 54 & 91 & 0.195 \\
Natural resources and environment & 44 & 58 & 0.010 \\
Philanthropy & 18 & 41 & 0.482 \\
Public health & 66 & 128 & 0.860 \\
Social justice & 40 & 72 & 0.639 \\
Youth & 15 & 34 & 0.545 \\
\hline
\end{tabular}


Table A3. Food waste/recovery.

\begin{tabular}{lrrr}
\hline Member Category & No & Yes & p-value \\
\hline Government staff & 141 & 33 & 0.484 \\
Elected officials & 51 & 15 & 0.235 \\
Anti-hunger/emergency food & 154 & 38 & 0.082 \\
College/university/community college & 151 & 35 & 0.481 \\
Community & 165 & 39 & 0.151 \\
Economic development & 100 & 19 & 0.393 \\
Elementary and secondary education & 88 & 23 & 0.295 \\
Faith-based organizations & 79 & 21 & 0.295 \\
Farm/food industry workers & 96 & 23 & 0.585 \\
Processing and distribution & 67 & 24 & 0.007 \\
Food production & 150 & 35 & 0.435 \\
Food retail & 100 & 23 & 0.768 \\
Food waste/recovery & 46 & 30 & 0.000 \\
Health care & 114 & 31 & 0.074 \\
Natural resources and environment & 77 & 25 & 0.020 \\
Philanthropy & 44 & 15 & 0.084 \\
Public health & 157 & 37 & 0.282 \\
Social justice & 89 & 23 & 0.325 \\
Youth & 39 & 10 & 0.622 \\
\hline
\end{tabular}

Table A4. Anti-hunger.

\begin{tabular}{lrrr}
\hline Member Category & No & Yes & $p$-value \\
\hline Government staff & 107 & 67 & 0.234 \\
Elected officials & 38 & 28 & 0.232 \\
Anti-hunger/emergency food & 114 & 78 & 0.001 \\
College/university/community college & 113 & 73 & 0.052 \\
Community & 128 & 76 & 0.423 \\
Economic development & 79 & 40 & 0.339 \\
Elementary and secondary education & 67 & 44 & 0.329 \\
Faith-based organizations & 54 & 46 & 0.008 \\
Farm/food industry workers & 78 & 41 & 0.499 \\
Processing and distribution & 56 & 35 & 0.610 \\
Food production & 119 & 66 & 0.575 \\
Food retail & 80 & 43 & 0.598 \\
Food waste/recovery & 47 & 29 & 0.709 \\
Health care & 82 & 63 & 0.003 \\
Natural resources and environment & 71 & 31 & 0.082 \\
Philanthropy & 36 & 23 & 0.642 \\
Public health & 123 & 71 & 0.929 \\
Social justice & 79 & 33 & 0.028 \\
Youth & 28 & 21 & 0.294 \\
\hline
\end{tabular}


Table A5. Land use planning.

\begin{tabular}{lrrr}
\hline Member Category & No & Yes & $p$-value \\
\hline Government staff & 127 & 47 & 0.568 \\
Elected officials & 48 & 18 & 0.800 \\
Anti-hunger/emergency food & 140 & 52 & 0.411 \\
College/university/community college & 141 & 45 & 0.136 \\
Community & 150 & 54 & 0.694 \\
Economic development & 90 & 29 & 0.522 \\
Elementary and secondary education & 90 & 21 & 0.015 \\
Faith-based organizations & 82 & 18 & 0.013 \\
Farm/food industry workers & 90 & 29 & 0.522 \\
Processing and distribution & 71 & 20 & 0.241 \\
Food production & 135 & 50 & 0.494 \\
Food retail & 88 & 35 & 0.379 \\
Food waste/recovery & 53 & 23 & 0.311 \\
Health care & 114 & 31 & 0.027 \\
Natural resources and environment & 71 & 31 & 0.182 \\
Philanthropy & 45 & 14 & 0.625 \\
Public health & 145 & 49 & 0.438 \\
Social justice & 77 & 35 & 0.080 \\
Youth & 34 & 15 & 0.418 \\
\hline
\end{tabular}

Table A6. Food production.

\begin{tabular}{lrrr}
\hline Member Category & No & Yes & $\boldsymbol{p}$-value \\
\hline Government staff & 118 & 56 & 0.499 \\
Elected officials & 44 & 22 & 0.637 \\
Anti-hunger/emergency food & 133 & 59 & 0.774 \\
College/university/community college & 128 & 58 & 0.941 \\
Community & 80 & 39 & 0.118 \\
Economic development & 81 & 38 & 0.768 \\
Elementary and secondary education & 78 & 33 & 0.664 \\
Faith-based organizations & 77 & 23 & 0.019 \\
Farm/food industry workers & 85 & 34 & 0.385 \\
Processing and distribution & 63 & 28 & 0.933 \\
Food production & 123 & 62 & 0.080 \\
Food retail & 84 & 39 & 0.822 \\
Food waste/recovery & 53 & 23 & 0.849 \\
Health care & 102 & 43 & 0.529 \\
Natural resources and environment & 65 & 37 & 0.123 \\
Philanthropy & 42 & 17 & 0.661 \\
Public health & 133 & 61 & 0.759 \\
Social justice & 81 & 31 & 0.269 \\
Youth & 35 & 14 & 0.667 \\
\hline
\end{tabular}


Cogitatio

Table A7. Economic development.

\begin{tabular}{lrrr}
\hline Member Category & No & Yes & p-value \\
\hline Government staff & 97 & 77 & 0.563 \\
Elected officials & 39 & 27 & 0.648 \\
Anti-hunger/emergency food & 113 & 79 & 0.111 \\
College/university/community college & 103 & 83 & 0.345 \\
Community & 43 & 76 & 0.521 \\
Economic development & 58 & 61 & 0.010 \\
Elementary and secondary education & 64 & 47 & 0.786 \\
Faith-based organizations & 61 & 39 & 0.248 \\
Farm/food industry workers & 67 & 52 & 0.883 \\
Processing and distribution & 51 & 40 & 0.858 \\
Food production & 101 & 84 & 0.146 \\
Food retail & 64 & 59 & 0.113 \\
Food waste/recovery & 46 & 30 & 0.413 \\
Health care & 82 & 63 & 0.933 \\
Natural resources and environment & 58 & 44 & 0.977 \\
Philanthropy & 29 & 30 & 0.169 \\
Public health & 110 & 84 & 0.965 \\
Social justice & 59 & 53 & 0.216 \\
Youth & 27 & 22 & 0.791 \\
\hline
\end{tabular}

